Dmitriy V. Galushko*

\title{
INFLUENCE OF LAW OF THE EUROPEAN UNION ON LEGAL SYSTEMS OF THIRD COUNTRIES: SOME CONTEMPORARY TENDENCIES
}

\begin{abstract}
The paper is devoted to the analysis of EU legal order's impact on non-member states. EU law serves as the main tool for this process as the expansion of EU law outside of the Union is one of the priorities of its external actions. This is implemented through conclusion of international treaties with third countries. The author investigated provisions of association and partnership agreements of the European Union with different countries. The conducted analysis lets us make conclusions on the character and ways of influence of EU law on legal systems of non-member states, which depend on the level of cooperation between the parties that is precisely determined by relevant international agreements.

Keywords: European Union, EU law, approximation, acquis communautaire, Russian Federation, international treaties, implementation.
\end{abstract}

\section{Introduction}

At present, the expansion of legal norms of the European Union beyond its borders is one of the most important areas of its foreign policy (Cardwell, 2012, p. 218). This applies, first of all, to relations with those states that are not part of it, but the stabilization of relations with them serves foreign policy interests of the expanding Union (Lavenex, 2004, p. 681). In addition, researchers draw attention to the fact that a relatively new characteristic of the EU is the adoption by its institutions of acts addressed to legal entities of third countries (the so-called extraterritorial effect) (Scott, 2014, p. 1343). This practice causes a lot of controversy from the point of view of the concept of state sovereignty, since it aims to impose on other subjects of international law a regime of cooperation that, under certain circumstances, may deprive them of the means to effectively protect their interests.

The legal basis of the EU influence on legal orders of third countries, namely, candidate countries and neighboring states, are relevant international treaties concluded with them. Moreover, when concluding international treaties with third countries, the

* PhD, Associate Professor, Department of International Law, Voronezh State University, Russia, email: galushkodv@gmail.com. 
European Union widely uses the practice of including in these agreements provisions similar to those contained in founding treaties or acts of EU institutions that are addressed to the Member States. This creates legal grounds for the assimilation of the provisions established by law of the European Union by the domestic legal systems of third countries (Hillion, 2005).

Among third countries with which the EU has treaty relations, the candidate states for accession and the neighboring states occupy a special place, since they are the ones which work most closely with the Union. The state acquires the legal status of an EU accession candidate after submitting an official application and a positive decision made by the EU Council to open a negotiation process with that state. According to Article 8 of the EU Treaty, the Union shall develop a special relationship with neighboring countries, aiming to establish an area of prosperity and good neighborliness, founded on the values of the Union and characterised by close and peaceful relations based on cooperation. To this end, the Union may conclude specific agreements with the countries concerned. These agreements may contain reciprocal rights and obligations as well as the possibility of undertaking activities jointly. Their implementation shall be the subject of periodic consultation (Consolidated version of the Treaty on European Union).

We would like to pay special attention to association and partnership agreements concluded by the Union with neighboring countries.

\section{The role of EU law in the association agreements}

The conclusion of association agreements with European countries is often perceived as a steppingstone towards EU membership (Phinnemore, 1999). However, there is no automatic link between association and accession prospects (Van Der Loo, Van Elsuwege \& Petrov, 2014). Nevertheless, due to conclusion of an association agreement a state is recognized as capable of negotiating accession to the EU. Nowadays these agreements have been concluded with all candidate countries, with some of the applicant states and other third countries. For example, in 2014, an Association Agreement was signed with Ukraine (Association Agreement between the European Union and its Member States, of the one part, and Ukraine, of the other part).

The closest cooperation within the framework of the association is provided for by the Agreement on the European Economic Area (hereinafter - EEA), which actually reproduces the main provisions of the EU Treaty and acts of the institutions of the Union, providing for their fullest recognition of EU law in cooperation areas stipulated by that Agreement. The emphasis is on the inclusion in national law of the EEA member states of entire blocks of EU law both by reproducing the provisions of the Treaty on the European Union in the Agreement on the EEA, as well as, by referring to the EU regulations and directives referred to in the annexes to the Agreement and acts of association bodies, created according to the Agreement and which provisions become part of the national legal orders of associated states. 
One of the ways for approximation of legislation is to introduce directives of EU institutions in the national legal systems of the associated countries through references to these acts or their inclusion in the annexes to the EEA Agreement or acts of association bodies. It should be specially noted that by implementing the provisions of the EU directives in the national legal orders of the associated countries, their national law is being brought closer to law of the European Union. In the same way, harmonization of national legislations in member countries is applied in the Union itself (Kaczorowska, 2011, p. 224).

As a rule, the provisions of the agreements relating to the adaptation of national legislation of associated countries to EU law should have the character of both "hard" and "soft" obligations of the parties depending on the areas in which the adaptation is carried out. However, the definition of the spheres themselves, as a rule, takes into account the special nature of relations with a particular country, although certain spheres, in particular, protection of intellectual property rights, competition law, etc., are enshrined in all association agreements (Ghazaryan, 2014, pp. 68-72).

When conducting adaptation, all associated states must deal with the same EU acts. In practice, there is a selective approach, when for certain associated countries or groups of countries, depending on goals and areas of cooperation defined by an agreement, from the whole mass of EU acts, those whose implementation should ensure that the parties fulfill their obligations are specially selected (Galushko, 2017, pp. 85-86). So, for the associated countries of Central and Eastern Europe, in May 1995, the White Paper "On the Preparation of the Associated Countries of Central and Eastern Europe for Integration into the Internal Market of the Union" was adopted by the EU Commission in order to determine specific obligations for joining the European Union. Particular attention was paid to the adaptation of national legislation of associated countries to law of the European Union and the expansion of EU law to these countries was also considered. The white paper serves as a reference to be used by current and future associate countries. Its provisions are not binding, but serve as a guide for the EU accession. As regards the practice of implementation of the EU acts included in the White Paper by the associated countries of Central and Eastern Europe, it comes down to the reception of the provisions of acts of EU institutions.

The adaptation of the legislation of the associated countries to EU law is more limited than that carried out within the framework of the EEA, since it covers only areas of cooperation clearly defined by European agreements. Another difference is that the adaptation of legislation of the state parties to agreements to EU law is carried out at two levels - internationally and at the EU level. Adaptation methods come down mainly to the accession of associated countries to the relevant multilateral international treaties that have already been implemented in EU law.

Based on the analysis of the experience of cooperation of the associated countries with the European Union, we can distinguish the following main ways of approximation between national law of these countries and EU law. Firstly, the adoption of national legal acts that take into account, to one degree or another, the provisions of EU law. The second way involves joining a non-EU country to international agreements that are binding for the $\mathrm{EU}$ and its member states. The third way is the inclusion of EU legal acts in national law. 
Another way is the mutual recognition by the parties of the legal norms in force in each of them. Finally, as a way of adaptation, the parallel adoption by the associated countries of normative acts that are identical or similar in meaning to the acts of the European Union can be used.

\section{Partnership and cooperation agreements as a basis for EU law expansion}

The European Union's Partnership and cooperation agreements with third countries define similar ways to bring national law of respective third countries closer to EU law. We are talking about concluding or joining international agreements, the adoption of national legal acts, provisions of which comply with the norms of the Union's law, as well as the mutual recognition by the parties of rules of the other party in a certain field. However, such a process is predominantly one-sided in nature, since its implementation is about bringing legal norms adopted by third countries in line with EU law.

Today, the European Union has concluded partnership and cooperation agreements with most of the countries that were part of the former USSR, among which there are both neighboring states and EU partner states, including the Russian Federation.

EU partnership and cooperation agreements may include provisions on the adaptation of relevant legislation of non-member states to law of the European Union, and the main ways of adaptation are joining the agreements to which the EU member states are parties, adoption of normative acts which provisions would comply with EU law, mutual recognition of relevant standards in force in participating countries. It should be noted that the partnership and cooperation agreements also require the creation of legal instruments relating to various fields and are not limited to issues of customs procedures and trade in goods.

The purpose of legal approximation of the Russian legal system to EU law was included in the Partnership and Cooperation Agreement between the European Communities and the Russian Federation (see Agreement on Partnership and Cooperation establishing a partnership between the European Communities and their Member States, of the one part, and the Russian Federation, of the other part), providing in Article 55, that "the Parties recognize that an important condition for strengthening the economic links between Russia and the Community is the approximation of legislation. Russia shall endeavour to ensure that its legislation will be gradually made compatible with that of the Community. The approximation of laws shall extend to the following areas in particular: company law, banking law, company accounts and taxes, protection of workers at the workplace, financial services, rules on competition, public procurement, protection of health and life of humans, animals and plants, the environment, consumer protection, indirect taxation, customs law, technical rules and standards, nuclear laws and regulations, transport (Agreement on Partnership and Cooperation establishing a partnership between the European Communities and their Member States, of the one part, and the Russian Federation, of the other part). 
The subsequent documents on cooperation between Russia and the EU confirmed the goal of legal approximation of the legal systems of both parties. The European Union's overall strategy towards Russia in 1999 specified that "the progressive approximation of legislation and standards between Russia and the European Union, in accordance with the PCA, will facilitate the creation of a common economic area" (Common Strategy of the European Union of 4 June 1999 on Russia (1999/414/CFSP)).

The scope of the partnership agreements with the EU penetrates deeply into the domestic policies and law of the parties. Thus, the subject of regulation of the partnership and cooperation agreements with Azerbaijan (see Partnership and Cooperation Agreement with Azerbaijan), Armenia (see Comprehensive and Enhanced Partnership Agreement with Armenia), Georgia (see Partnership and Cooperation Agreement with Georgia), Tajikistan (see Partnership and Cooperation Agreement with Tajikistan) and Turkmenistan (see Partnership and Cooperation Agreement with Turkmenistan) is, among other things, also cooperation in relation to democracy and the protection of human rights. In agreements with the Russian Federation and Uzbekistan, the subject of cooperation, for example, is the prevention and combating of illegal migration, drug trafficking, and the laundering of "dirty" money. For the countries, this state of affairs is a serious test, since the full implementation of such agreements will require far-reaching efforts to adapt domestic legislation in various directions: both in the political and economic spheres, and in matters of improving administrative management and legal proceedings. Extraordinary measures must also be taken in the direction of reforming and restructuring the economy to establish the necessary trust between market participants, as well as institutions that oversee their activities. Thus third countries, parties to partnership and cooperation agreements, in adaptation of their national legislation use selective approach, choosing EU legal norms according to their interests, possibilities and needs in relation to the Union and other countries.

To a large extent, the association agreements are similar to partnership and cooperation agreements (this applies to the provisions on political dialogue, the establishment of enterprises, the movement of labor and capital and on cooperation in the economic, financial and cultural fields). At the same time, the differences that exist between association agreements and partnership and cooperation agreements are primarily due to trade issues, since the first ones are preferential agreements aimed at creating free trade zones for goods and services and cover almost all trade issues between the parties.

If the partnership and cooperation agreements are concluded with states that chose the usual format of interstate cooperation, association agreements (stabilization and association agreements) are concluded with the aim of preparing the state for membership in the European Union and provide for a greater degree of self-restriction of sovereign rights in favour of the supranational organization.

In particular, the bodies of cooperation between states and the EU, on the basis of the partnership and cooperation agreements, only make advisory decisions, which are covered by the concept of "soft law", being essentially political arrangements. In this case, the state has four possible options for behaviour: a) fully implement recommendations submitted by the EU regarding the format of cooperation at the national level and take 
appropriate measures; b) carry out a partial implementation of the recommended norm; c) save the status quo; d) improve the mechanism for implementing existing legislation. If the provisions of the recommendations submitted by the EU are not taken into account or are not fully taken into account, the state will not be held legally liable, unlike the EU member states, which are obliged to implement acquis communautaire in their own legal systems. This circumstance can only create obstacles in the further process of a state's EU integration.

At the same time, in the association agreements it is assumed that common bodies can be empowered to make binding decisions. For institutional arrangements created through association agreements, it is usually used a structure based on the model of EU institutions, but with limited functions. In addition, unlike the partnership and cooperation agreements, an indispensable economic basis for association with the EU is the creation of a free trade zone or a customs union between the Union and the associated country, the legal regime of which affects the state's exercise of its sovereign powers in the economic sphere. So, the free trade zone provides for the abolition of customs rates, taxes, fees and quantitative restrictions in mutual trade of goods between its participants. At the same time, the states retain the right to independently carry out their trade policy with third countries.

The legal regime of the free trade zone does not require a review of existing free trade agreements with other countries. Therefore, a country, at its discretion, may simultaneously introduce several free trade zones with different groups of countries, including the EU; however, it should not violate its obligations in accordance with the concluded agreements on the establishment of this trade regime. But the customs union is a higher level of integration and involves the implementation of certain restrictions on the right of the state to exercise sovereign rights in relation to foreign trade. According to the rules of this regime, it provides not only the abolition of duties and other trade fees between its participants, but also the unification of foreign trade rules with third countries and the introduction of a single customs tariff for all its participants. State membership in the customs union with the European Union excludes the simultaneous possibility of its membership in other customs unions. Thus, the customs union restricts the parties' right of independent trade policy with third states and requires coordination with other members of the association.

\section{Conclusion}

In conclusion, it can be noted that the means of the influence of the European Union on the legal systems of third countries is EU law, which turns into an instrument for the effective protection of the interests of the European integration association and its member states in relations with other subjects. As the analysis of the practice of legal regulation of EU cooperation with third countries shows, this is possible, first of all, due to the autonomy of law and the expansion of its norms outside the EU, which is accompanied by the process of adaptation of national legislation of third countries to the standards of the 
EU legal system. Thus, third countries are gradually becoming involved in the processes of legal integration within the framework of the European Union.

Such an involvement also depends on a type of relations between the state and the European Union and their intensity as well as aims of cooperation between two parties. Countries, parties of association agreements, seeing these treaties as a way for the future accession to the Union, are more likely to adapt their legislation to the EU legal norms in the light of potential membership, fixing the obligations in relevant agreements. Third countries, parties to partnership and cooperation agreements, in adaptation of their national legislation use selective approach, choosing EU legal norms according to their interests, possibilities and needs in relation to the Union and other countries. In any case, influence of the EU legal order on the legal systems of the third countries is one-sided, prescribing transposition of acquis communautaire to national law of non-member states depending on the level of cooperation between the parties, which is precisely determined by relevant international agreements.

\section{References}

Cardwell, P.J. 2012. EU External Relations Law and Policy in the Post-Lisbon Era. The Hague: Springer

Galushko, D. V. 2017. To the Question of the Legal Approximation between the European Union and the Russian Federation. InterEU law east: journal for the international and European law, economics and market integrations, 4(2), pp. 81-89.

Ghazaryan, N. 2014. The European Neighbourhood Policy and the Democratic Values of the EU: A Legal Analysis. Oxford: Hart Publishing.

Hillion, Ch. 2005. The evolving system of the EU external relations as evidenced in the EU partnerships with Russia and Ukraine. Leiden.

Kaczorowska, A. 2011. European Union Law. London: Routledge.

Lavenex, S. 2004. EU External Governance in "Wider Europe". Journal of European Public Policy, 11(4), pp. 680-700.

Phinnemore, D. 1999. Association: Stepping-Stone or Alternative to EU Membership?. Sheffield.

Scott, J. 2014. The new EU "extraterritoriality". Common Market Law Review, 51(5), pp. 1343-1380.

\section{Website references}

Van Der Loo, G., Van Elsuwege, P. \& Petrov, R. 2014. The EU-Ukraine association agreement: assessment of an innovative legal instrument, EUI LAW, 9. Available at: http://hdl.handle.net/1814/32031, last visited 1 November 2019. 


\section{Legal sources}

Agreement on Partnership and Cooperation establishing a partnership between the European Communities and their Member States, of the one part, and the Russian Federation, of the other part. Available at: https://russiaeu.ru/userfiles/ file/partnership_and_cooperation_agreement_1997_english.pdf, last visited 1 November 2019.

Agreement on the European Economic Area. Available at: http://www.efta.int/media/ documents/legal-texts/eea/the-eea-agreement/Main\%20Text\%20of\%20the $\% 20$ Agreement/EEAagreement.pdf, last visited 1 November 2019.

Association Agreement between the European Union and its Member States, of the one part, and Ukraine, of the other part. Available at: https://eur-lex.europa.eu/ legal-content/EN/ALL/?uri=CELEX\%3A22014A0529\%2801\%29, last visited 1 November 2019.

Common Strategy of the European Union of 4 June 1999 on Russia (1999/414/CFSP). Available at: https://eur-lex.europa.eu/legal-content/EN/TXT/?uri=CELEX:31999E0414, last visited 1 November 2019.

Comprehensive and Enhanced Partnership Agreement with Armenia. Comprehensive and Enhanced Partnership Agreement between the European Union and the European Atomic Energy Community and their Member States, of the one part and the Republic of Armenia, of the other part. Available at: https://eeas.europa.eu/sites/ eeas/files/eu-armenia_comprehensive_and_enhanced_partnership_agreement_ cepa.pdf, last visited 1 November 2019.

Consolidated version of the Treaty on European Union. Available at: https://eur-lex. europa.eu/legal-content/EN/TXT/?uri=celex\%3A12012M\%2FTXT, last visited 1 November 2019.

Partnership and Cooperation Agreement with Georgia. Partnership and Cooperation Agreement between the European Communities and their Member States, of the one part, and Georgia, of the other part. Available at: http://ec.europa. eu/world/agreements/prepareCreateTreatiesWorkspace/treatiesGeneralData. do?step=0\&redirect=true\&treatyId=188, last visited 1 November 2019.

Partnership and Cooperation Agreement with Tajikistan. Partnership and Cooperation Agreement establishing a partnership between the European Communities and their Member States, of the one part, and the Republic of Tajikistan, of the other part. Available at: https://eur-lex.europa.eu/legal-content/EN/TXT/ PDF/?uri=CELEX:22009A1229(01)\&qid=1495981934450\&from=EN, last visited 1 November 2019.

Partnership and Cooperation Agreement with Turkmenistan. Partnership and Cooperation Agreement establishing a Partnership between the European Communities and their Member States, of the one part, and Turkmenistan, of the other part. Available at: http://www.europarl.europa.eu/doceo/document/TA-8-2019-0146_EN.html, last visited 1 November 2019. 
Partnership and Cooperation Agreement with Azerbaijan. Partnership and Cooperation Agreement, establishing a partnership between the European Communities and their Member States, of the one part, and the Republic of Azerbaijan, of the other part. Available at: https://eeas.europa.eu/sites/eeas/files/eu-az_pca_full_text.pdf, last visited 1 November 2019.

White Paper on the Preparation of the Associated Countries of Central and Eastern Europe for Integration into the Internal Market of the Union. Available at: http://www. cvce.eu/en/obj/white_paper_on_the_preparation_of_the_associated_countries_ of_central_and_eastern_europe_for_integration_into_the_internal_market_of_ the_union_com_95_163-en-f3207cf5-df8b-475a-bd06-6fc7d80b0c9e.html, last visited 1 November 2019.

\title{
Dr Dmitriy V. Galushko
}

Docent na departmanu za međunarodno pravo, Državni univerzitet u Voronježu, Rusija e-mail: galushkodv@gmail.com

\section{UTICAJ PRAVA EVROPSKE UNIJE NA PRAVNE SISTEME TREĆIH ZEMALJA: NEKE SAVREMENE TENDENCIJE}

\author{
Sažetak
}

Rad je posvećen analizi uticaja pravnog poretka Evropske unije na države nečlanice. Pravo EU služi kao glavno sredstvo u ovom procesu, imajući u vidu da je širenje prava EU izvan Unije jedan od prioriteta njenog spoljašnjeg delovanja. Ovo se sprovodi kroz zaključivanje međunarodnih ugovora sa trećim državama. Autor je ispitivao odredbe ugovora o pristupanju i partnerstvu sa trećim državama. Sprovedena analiza omogućava izvođenje zaključka o karakteru i načinima na koje pravo EU utiče na pravne sisteme država nečlanica, što zavisi od stepena saradnje između strana, a što se precizno utvrđuje relevantnim međunarodnim ugovorima.

Ključne reči: Evropska unija, pravo EU, aproksimacija, acquis communautaire, Ruska Federacija, međunarodni ugovori, implementacija.

Article history:

Received: 19 November 2019 Accepted: 27 January 2020 